\title{
Cultivation of Pleurotus ostreatus Mushroom on Substrates Made of Cellulose Fibre Rejects: Product Quality and Spent Substrate Fuel Properties
}

\author{
Alejandro Grimm ${ }^{1}$ (D) Lill Eilertsen $^{1,2} \cdot$ Feng Chen $^{1} \cdot$ Renyuan Huang ${ }^{3} \cdot$ Lars Atterhem $^{4} \cdot$ Shaojun Xiong ${ }^{1}$
}

Received: 15 November 2019 / Accepted: 18 November 2020 / Published online: 3 December 2020

(c) The Author(s) 2020

\begin{abstract}
This paper explores an alternative valorisation method for high-moisture content waste streams from the pulp and paper industry. Cellulose fibre rejects from industrial-scale recycling/pulping of waste paper was used as an ingredient in substrates for cultivation of Pleurotus ostreatus, commonly known as oyster mushroom. Three substrates with 40, 60, and $80 \mathrm{wt} \%$ fibre rejects were tested, and a conventional substrate formula based on birch (Betula ssp.) sawdust was used for comparison. The spent mushroom substrate (SMS) fuel characteristics were assessed through ashing procedures. Mycelium growth was faster on substrates based on fibre rejects. The average biological efficiencies of the first flush of fruit bodies were between 29 and $36 \%$ compared to $42 \%$ for birch sawdust substrates. The fruit bodies had good nutritional values, i.e., crude protein (22-25 wt\% d.b.), crude fat (3-3.5 wt\% d.b.), crude fibre (8-10 wt\% d.b.), and carbohydrates (57-62 wt \% d.b.). The concentrations of heavy metals, 5-10 $\mu \mathrm{g} / \mathrm{kg} \mathrm{Pb}, 19-28 \mu \mathrm{g} / \mathrm{kg} \mathrm{Cd}, 5-6 \mu \mathrm{g} / \mathrm{kg} \mathrm{Hg}$, and 26-53 $\mu \mathrm{g} / \mathrm{kg}$ As were well below the limit values for food products set in EU regulations. The SMS could be used as fuel for direct combustion or co-combusted with other biomasses.
\end{abstract}

\section{Graphic Abstract}



Keywords Edible fungus $\cdot$ Nutritional values $\cdot$ Heavy metals $\cdot$ Fuel characterization $\cdot$ Circular economy

Alejandro Grimm

Alejandro.Grimm@slu.se

1 Department of Forest Biomaterials and Technology, Swedish University of Agricultural Sciences, 90183 Umeå, Sweden

2 Department of Forest Genetics and Plant Physiology, Umeå Plant Science Center, Swedish University of Agricultural Sciences, 90183 Umeå, Sweden

3 Swedfungi AB, 90740 Umeå, Sweden

4 Biosteam AB, 93793 Burträsk, Sweden

\section{Statement of Novelty}

Many different types of biowaste materials contain components that can be converted into high value-added biobased products before being used for energy purposes. This study is meant to show how cellulose-rich fibre rejects ('secondary wastes') from industrial-scale recycling/pulping of waste paper ('primary wastes') can be used as an ingredient in substrates for cultivation of edible mushrooms, and how the spent substrates ('tertiary wastes') can be used as solid 
biofuel. Today, fibre rejects are mostly disposed of in landfills or, to a lesser extent, used as fuel in waste-to-energy plants. To the author's knowledge, the information about the suitability of fibre rejects for combined production of edible mushrooms and biofuels is scarce.

\section{Introduction}

According to the International Council on Clean Transportation [1], approximately $225 \mathrm{Mt}$ of diverse residues including, e.g., waste paper, wood, food, and plant materials are annually generated in Europe. Wastes generated during the recycling/pulping of waste paper, so-called 'rejects', are considered a problematic material from both the environmental and economic point of view. As much as $15-25 \mathrm{wt} \%$ of the raw waste paper can end up as rejects during the pulping process [2]. The rejects can be subdivided into different types according to their composition [3], and some of these can be seen as an interesting raw material for the development of a circular economy. Rejects that contain a high amount of cellulose fibre, not suitable for the production of paper, could be used to cultivate high value-added biobased products such as edible mushrooms. The latter are the fruit bodies of basidiomycetes with a saprotrophic lifestyle. These basidiomycetes are divided into primary, secondary, and tertiary decomposers $[4,5]$. Primary decomposer fungi such as the Pleurotus spp., Lentinula edodes, and Grifola frondosa, have the ability to degrade and use plant material components such as cellulose, hemicellulose, and lignin as carbon sources.

Edible mushrooms are cultivated and consumed worldwide, e.g., Pleurotus spp. and Lentinula edodes, with a protein content of about $30 \mathrm{wt} \%$ and $18 \mathrm{wt} \%$ d.b., respectively [6], are two of the most popular on the global market. Many species have also a health-promoting effect [7], and some are used for extraction of bioactive compounds $[8,9]$. According to Royse et al. [10], the world annual production of cultivated edible mushrooms is about $34 \mathrm{Mt}$ with a 30 -fold increase since 1978, which corresponds to a value of 34 billion USD. China is today the largest producer and exporter (with $80 \%$ of the world market) of cultivated edible mushrooms, while the EU and America stand for approximately $10 \%$ of the global production.

Cultivation of primary decomposer mushroom results in considerable quantities of spent substrate (SMS). The latter can be used as a component of substrates for mushrooms that grow on composts, but not always in sufficient quantities to solve the problem of their accumulation in producing areas where they represent a pollution risk $[11,12]$. In a wellmanaged mushroom industry, approximately $70 \mathrm{wt} \%$ d.b. of the initial substrate may remain as SMS [13, 14]. Disposal of SMS is also costly due to the high transportation volumes
[15]. This emphasizes a necessity for the development of smart solutions to reduce environmental problems and costs tied to the production process.

Mushrooms such as Pleurotus spp. are cultivated on substrates made of various lignocellulosic wastes [14, 16-19], and to a lesser extent on different types of waste paper or cellulose-rich materials [20-24]. This paper evaluates the suitability of fibre rejects ('secondary waste') from industrial-scale recycling/pulping of waste paper ('primary waste') as an ingredient in substrates for cultivation of Pleurotus ostreatus mushroom, and the possibility of using spent substrates ('tertiary waste') as fuel for the generation of the heat necessary for the substrate pasteurization and mushroom cultivation processes. The main goal is to promote the establishment of an integrated production model to achieve almost zero-waste development.

\section{Materials and Methods}

\section{Substrate Raw Materials}

Mushroom substrate ingredients included: (a) Light coarse fibre rejects, which consists mainly of cellulose fibre and impurities such as limestone and different silicates, was collected from SCA Obbola, Umeå, Sweden; (b) Sawdust (particle size $<2 \mathrm{~mm}$ ), generated during the processing of birch (Betula ssp.) timber, was collected from a sawmill in the province of Västerbotten, Sweden; and (c) Wheat bran (Lantmännen Lantbruk, Sweden) was used as a nutrient source in the substrates to promote productivity.

\section{Produced Substrate Compositions}

Substrate ingredients were mixed on a dry basis according to Table 1 . Wheat bran ( $20 \mathrm{wt} \%)$ was added to all substrates. Three substrates with an increasing amount of fibre rejects, i.e., FR40, FR60, and FR80 were produced. A conventional substrate formula for the cultivation of Pleurotus ostreatus based on birch sawdust (FR00) was used for comparison. During the mixing process, water was added to obtain mixtures with a moisture content of approximately $65 \mathrm{wt} \%$

Table 1 Produced substrate compositions

\begin{tabular}{lcllll}
\hline Substrate ID & \multicolumn{2}{l}{ Ingredients in initial substrate wt\% d.b. } & $\mathrm{pH}$ \\
\cline { 2 - 5 } & Fibre rejects & $\begin{array}{l}\text { Birch saw- } \\
\text { dust }\end{array}$ & Wheat bran & $\mathrm{CaCO}_{3}$ & \\
\hline FR00 & 0 & 80 & 20 & 1 & 6.36 \\
FR40 & 40 & 40 & 20 & 0.5 & 6.55 \\
FR60 & 60 & 20 & 20 & 0 & 6.62 \\
FR80 & 80 & 0 & 20 & 0 & 6.75 \\
\hline
\end{tabular}


w.b. The $\mathrm{pH}$ of the substrates was determined according to Sithole [25], by boiling water extraction for $10 \mathrm{~min}$ and measuring the $\mathrm{pH}$ of the cooled extract with a $\mathrm{pH}$ meter (Sension + PH31). The pH of the FR00 and FR40 substrates was too low for mycelium growth and, therefore, was adjusted by adding small amounts (Table 1 ) of calcium carbonate $\left(\mathrm{CaCO}_{3}\right)$. For FR60 and FR80 there was no need to include a buffer reagent because the fibre rejects contain $\mathrm{CaCO}_{3}$ that is used as filler in paper and end up in the rejects during pulping of the waste paper. The substrates were packed into polypropylene bags with inbuilt microporous filters (Microsac) for gas exchange that allows mycelia to breathe. Each bag was filled with $1 \mathrm{~kg}$ w.b. of substrate forming a cylindrical block of approximately $11 \mathrm{~cm}$ in diameter and $15-16 \mathrm{~cm}$ in height and then sealed with a plastic clip. The substrate bags were prepared such that there were 20 replicates for each substrate with fibre rejects, i.e., FR40 to FR80, and 4 replicates for FR00.

Representative samples of the produced substrates were dried at $60{ }^{\circ} \mathrm{C}$ for $72 \mathrm{~h}$, thoroughly homogenised by grinding them in a hammer mill to $0.5 \mathrm{~mm}$, and then analysed at a certified laboratory (Eurofins, Sweden) for the contents of ash (SS-EN ISO 18122 / SS-EN 15403), lower heating value (LHV) determined under constant pressure (SS-EN14918/15,400/ISO1928), main elements CHNO (SS-EN ISO 16948 / SS-EN 15407), main ash-forming elements (EN 14385 and NMKL 161:1998 mod./ICP-AES), Cl (EN ISO 16994:2016), S (SS 187177:1991), and trace elements (EN 13656 mod. / ICP-MS). The results are shown in Table 2.

\section{Substrate Pasteurisation Treatment}

Pasteurisation was conducted in a chamber using hot air according to our innovation [26-28]. The used method proved to be more energy-efficient and cost-effective than conventional methods via steaming. The pasteurisation temperature and the treatment time were controlled by using 'control substrates' to which thermocouples (type K) were placed at the core of each cylinder. The treatment temperature was $75^{\circ} \mathrm{C}$ and the treatment time was $2 \mathrm{~h}$ measured from the moment when the core of the cylindrical block reached the designated temperature. Process parameters were recorded using a computerized system. The pasteurisation was terminated when the required time was reached. The substrates were then left overnight in the chamber to cool to room temperature.

\section{Inoculation and Incubation}

A white-rot fungi, grey oyster (Pleurotus ostreatus) strain M2140, was used as model species. Commercial grain spawn from Svampkungen AB was used for inoculation
Table 2 Characterization of the produced mushroom substrates: ash content, low heating value, main elements, main ash-forming, and trace elements

\begin{tabular}{|c|c|c|c|c|c|}
\hline & Unit & FR00 & FR40 & FR60 & FR80 \\
\hline Ash & $\mathrm{wt} \%$ & 2.8 & 22.1 & 31.7 & 41.4 \\
\hline LHV & $\mathrm{MJ} / \mathrm{kg}$ & 19.6 & 14.7 & 12.4 & 11.2 \\
\hline $\mathrm{C}$ & $\mathrm{wt} \%$ & 49.3 & 41.4 & 37.6 & 32.5 \\
\hline $\mathrm{H}$ & $\mathrm{wt} \%$ & 5.9 & 4.78 & 4.2 & 3.8 \\
\hline $\mathrm{N}$ & $\mathrm{wt} \%$ & 1.2 & 0.81 & 0.62 & 0.42 \\
\hline $\mathrm{O}$ (diff.) & $\mathrm{wt} \%$ & 40.7 & 30.7 & 25.7 & 21.7 \\
\hline $\mathrm{C} / \mathrm{N}^{\mathrm{a}}$ & - & 41 & 51 & 61 & 77 \\
\hline S & $\mathrm{wt} \%$ & 0.086 & 0.071 & 0.075 & 0.082 \\
\hline $\mathrm{Cl}$ & $\mathrm{wt} \%$ & 0.011 & 0.101 & 0.104 & 0.108 \\
\hline $\mathrm{Ca}$ & $\mathrm{mg} / \mathrm{kg}$ & 22,300 & 92,000 & 94,000 & 130,000 \\
\hline $\mathrm{Si}$ & $\mathrm{mg} / \mathrm{kg}$ & 530 & 17,000 & 25,000 & 26,000 \\
\hline $\mathrm{Al}$ & $\mathrm{mg} / \mathrm{kg}$ & 72 & 7700 & 8900 & 9800 \\
\hline K & $\mathrm{mg} / \mathrm{kg}$ & 7000 & 2800 & 2600 & 2300 \\
\hline $\mathrm{Na}$ & $\mathrm{mg} / \mathrm{kg}$ & 53 & 580 & 660 & 930 \\
\hline $\mathrm{Mg}$ & $\mathrm{mg} / \mathrm{kg}$ & 2200 & 2300 & 2500 & 3200 \\
\hline $\mathrm{Fe}$ & $\mathrm{mg} / \mathrm{kg}$ & 100 & 1300 & 1500 & 2000 \\
\hline $\mathrm{P}$ & $\mathrm{mg} / \mathrm{kg}$ & 5900 & 2900 & 1700 & 1500 \\
\hline $\mathrm{Zn}$ & $\mathrm{mg} / \mathrm{kg}$ & 80 & 110 & 130 & 190 \\
\hline $\mathrm{Pb}$ & $\mathrm{mg} / \mathrm{kg}$ & 0.73 & 11 & 13 & 23 \\
\hline $\mathrm{Cd}$ & $\mathrm{mg} / \mathrm{kg}$ & 0.43 & 0.30 & 0.32 & 0.37 \\
\hline $\mathrm{Hg}$ & $\mathrm{mg} / \mathrm{kg}$ & 0.021 & 0.025 & 0.028 & 0.036 \\
\hline As & $\mathrm{mg} / \mathrm{kg}$ & 0.053 & 0.3 & 0.39 & 0.69 \\
\hline $\mathrm{Ba}$ & $\mathrm{mg} / \mathrm{kg}$ & 16 & 102 & 150 & 201 \\
\hline $\mathrm{Cu}$ & $\mathrm{mg} / \mathrm{kg}$ & 11 & 44 & 81 & 100 \\
\hline $\mathrm{Cr}$ & $\mathrm{mg} / \mathrm{kg}$ & 0.29 & 8 & 12 & 16 \\
\hline Mn & $\mathrm{mg} / \mathrm{kg}$ & 93 & 100 & 105 & 110 \\
\hline Mo & $\mathrm{mg} / \mathrm{kg}$ & 0.44 & 1.7 & 2.4 & 2.9 \\
\hline $\mathrm{Be}$ & $\mathrm{mg} / \mathrm{kg}$ & 0.053 & 0.1 & 0.12 & 0.16 \\
\hline
\end{tabular}

All values are given in dry basis

${ }^{\mathrm{a}}$ Weight ratio

that was carried out in a sterile hood. The inoculum was supplied to each substrate bag in a ratio of $2.5 \mathrm{wt} \%$ w.b.

The inoculated bags were placed in a cultivating room where light, temperature, and relative ambient humidity were controlled. During the first 2-4 weeks after the inoculation, the substrate bags were kept in total darkness at a temperature of around $22-24{ }^{\circ} \mathrm{C}$ and relative ambient humidity of approximately $70 \%$. When the entire substrate block was covered with mycelia the maturation phase was induced using light $<500 \mathrm{~lx}$ and air temperature of around 16-18 ${ }^{\circ} \mathrm{C}$. The substrate bags were then opened and onethird of the top plastic packing film removed. Next, the relative ambient humidity of the cultivating room was increased to around 85-90\%. After two weeks, the first flush of mushroom fruit bodies started to develop. 


\section{Mycelium Growth-Rate and Biological Efficiency}

The mycelium growth-rate was estimated by using imaging techniques. Photographs of each substrate bag on days 15 and 23 were taken with a digital camera. The percentage of hyphae coverage on the cylinders lateral surface was estimated by using an image processing software (ImageJ).

In this work, only the first flush of fruit bodies was harvested. This is a common practice in many European mushroom industries, especially in countries where labour costs are high. The biological efficiency (BE) of the first flush was calculated according to Eq. 1.

$B E(\%)=\frac{F W_{f . f .}}{D W_{s}} \times 100$

where $\mathrm{BE}$ is the biological efficiency in per cent; $\mathrm{FW}_{\mathrm{ff}}$ the weight (g) (normalised to $90 \%$ moisture content, w.b.) of manually harvested fresh fruit bodies per bag; and $\mathrm{DW}_{\mathrm{s}}$ the weight $(\mathrm{g}$ ) of dry substrate per bag before inoculation.

\section{Mushroom Fruit Bodies Characterization}

All harvested mushroom fruit bodies from each substrate were collected and treated as individual samples. Samples used for analyses of chemical composition were ovendried at $45{ }^{\circ} \mathrm{C}$ for $72 \mathrm{~h}$, ground into a powder, and kept in airtight plastic bags until needed. Representative samples were analysed for the contents of moisture, protein, fat, carbohydrates, and ash using the Association of Official Analytical Chemists procedures [29]. The crude protein content $(\mathrm{N} \times 4.38)$ of the samples was estimated by the macro-Kjeldahl method. The crude fat was determined by extracting a known weight of mushroom sample with petroleum ether using a Soxhlet apparatus. The ash content was determined by incineration at $550{ }^{\circ} \mathrm{C}$. The total carbohydrates was calculated by difference: total carbohydrates $=100-($ moisture + protein + fat + ash $)[30]$. The crude fibre content was determined by traditional methods for the analysis of feed and plant materials [31]. The gross energy content was calculated according to the following equation: Energy $(\mathrm{kcal})=4 \times\left(\mathrm{g}_{\text {protein }}+\mathrm{g}_{\text {carbohydrate }}\right)+9 \times \mathrm{g}$ fat [19]. The analysis of main minerals, i.e., $\mathrm{Ca}, \mathrm{Mg}, \mathrm{K}, \mathrm{Na}$, $\mathrm{P}$, and $\mathrm{S}$, was performed according to the methods described by Bahlsberg-Pålsson [32]. The contents of heavy metals were analysed according to the BS EN 13804:2013 standard method.

\section{Spent Mushroom Substrates Fuel Characterization}

The SMS's were oven-dried at $105^{\circ} \mathrm{C}$ until constant weight for determination of the moisture content. Representative samples from each type of substrate were ground to $0.5 \mathrm{~mm}$ and then combusted in a laboratory-scale muffle furnace at a temperature of $1000{ }^{\circ} \mathrm{C}$. Ground SMS samples (100 g) were placed in alumina crucibles to give a layer of approximately $20 \mathrm{~mm}$ thickness. The temperature of the furnace was increased at a rate of approximately $10{ }^{\circ} \mathrm{C} / \mathrm{min}$ and kept at the designated temperature for $1 \mathrm{~h}$ because sample weight loss was found to be constant beyond this time. After the treatment, the furnace was turned off and the samples were allowed to cool to room temperature.

Ash samples were thoroughly homogenised by grinding them in a mixer mill (MM 400 Retsch GmbH, Germany). The elemental compositions of ground samples were analysed using a Carl Zeiss EVO LS15 scanning electron microscope (SEM) with a LaB6 electron source and equipped with an Oxford Instruments Xmax-80 energy dispersive $\mathrm{X}$-ray spectrometer (EDS). The instrument was operated at low vacuum $(50 \mathrm{~Pa})$, an accelerating voltage of $20 \mathrm{kV}$, and a probe current of $500 \mathrm{pA}$. Images were taken with a backscattered electron (BSE) detector. Ground ash samples were mounted onto carbon-adhesive tape before analysis. For each sample, the average elemental concentrations of main ash-forming elements were determined based on 4 area-analyses. The acquisition time for each measurement was $500 \mathrm{k}$ counts.

\section{Statistical Evaluation of Experimental Data}

All experiments and chemical analyses were performed such that there were at least three replicates for each experiment or analysis. Results are expressed as mean values \pm standard error. The evaluation of the data obtained from mycelium growth-rate, days from inoculation to harvest of the first flush, and biological efficiency measurements was carried out by analysis of variance according to the Tukey's multiple comparison test using the SPSS Statistics 21.0 software. Differences were considered significant at $p<0.05$.

\section{Results and Discussion}

\section{Mycelium Growth-Rate and Biological Efficiency}

Mycelia of $P$. ostreatus mushroom colonized and grew well on all studied substrates with different amounts of fibre rejects. The mycelium growth on both day 15 and day 23 ( $\mathrm{p}<0.05$ in both cases), Fig. 1, was significantly faster in the fibre rejects based substrates (FR40 to FR80) than in the birch sawdust substrate (FR00). The positive correlation between mycelium growth and the amount of fibre rejects in the substrate was probably because the fibre reject is mostly composed of cellulose that is easier to digest by fungi. The lignin content in birch is $\sim 20 \mathrm{wt} \%$ d.b. and in wheat bran 


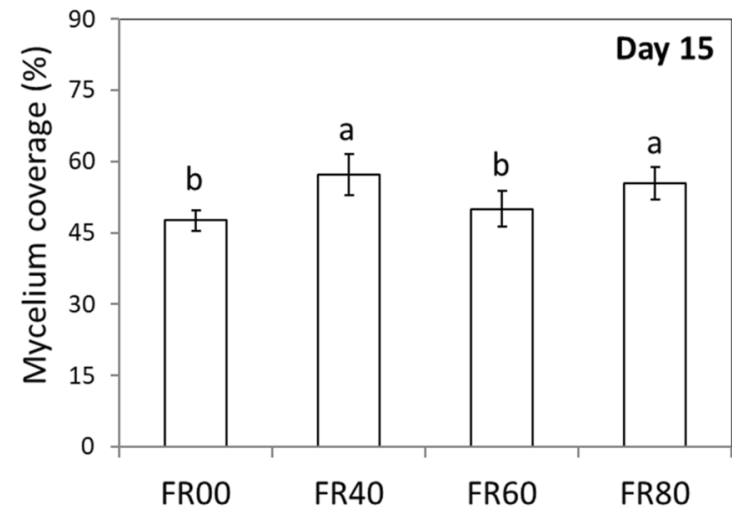

Fig. 1 Mycelium growth of $P$. ostreatus mushroom during colonization/incubation. Mycelium coverage is expressed as the percentage of hyphae coverage on the lateral surface of the cylindrical substrate block. Bars refer to the mean \pm standard error ( $n=4$ for the FR00 sub-

is $\sim 12 \mathrm{wt} \%$ d.b. When the amount of fibre rejects in the substrate increase, the ratio of lignin/cellulose decreases, which probably led to a higher mycelium growth-rate. Another hypothetical explanation could be related to the higher copper contents in the fibre rejects substrates (as shown in Table 2). Copper is a cofactor of laccase enzymes [33] and is known to induce this lignin-degrading enzyme, which might plausibly result in even the cellulose bounded with lignin in birch and bran substrate components to be released faster and become available for mycelium growth in fibre reject substrates. On the other hand, the differences in the substrates ash contents (Table 2) could be the reason why the mycelium growth in FR60 and FR80 was lower than in FR40.

The fibre rejects showed also a significant effect on the days from inoculation to harvest of the first flush (Fig. 2a) and the average BE (Fig. 2b) ( $p<0.05$ for both). The first



Fig. 2 Days from inoculation to harvest of the first flush (a) and average biological efficiency (b) of fresh $P$. ostreatus fruit bodies. Bars refer to the mean \pm standard error $(n=4$ for the FR00 substrate, and

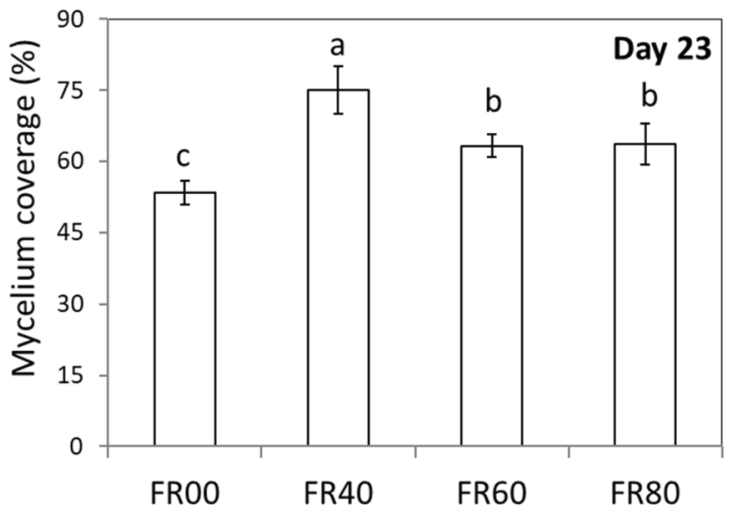

strate, and $\mathrm{n}=20$ for the FR40, FR60, and FR80 substrates). Different letters over the bars indicate statistically significant differences (Tukey's multiple comparison test, $p<0.05$ ) between substrates

flush of fruit bodies grown on fibre rejects substrates were harvested between 34 and 38 days after inoculation, 7 to 10 days earlier than those grown on FR00 substrates. The average BEs were between 29 and $36 \%$ (normalised to $90 \%$ moisture content) for the fibre rejects based substrates, but $42 \%$ for the FR00 substrate. The fruit body development was possibly affected by the substrate ash content. As shown in Table 2, the ash content of the FR00 substrate is $2.8 \mathrm{wt} \%$ d.b. and that of FR80 is $41.4 \mathrm{wt} \%$ d.b. This means that the amount of available organic material is considerably reduced when the amount of fibre rejects in the substrate increase, which probably led to a lower BE, Fig. 2b. The fastest mycelium colonization could, somehow, compensate the lower BE. There is also room for improving the substrate formulation by, e.g., removing ash/solid impurities from the raw fibre rejects, or by the addition of supplements and additives.

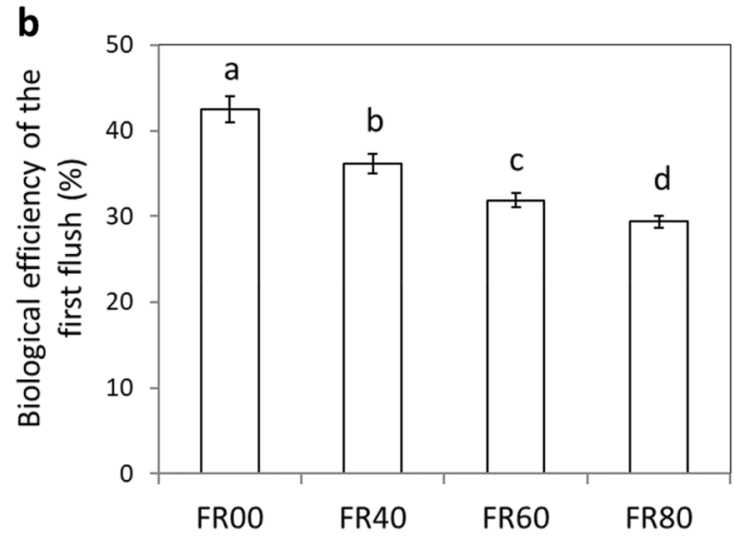

$\mathrm{n}=20$ for the FR40, FR60, and FR80 substrates). Different letters over the bars indicate statistically significant differences (Tukey's multiple comparison test, $p<0.05$ ) between substrates 
The results obtained in this study are in relatively good agreement with previous studies in which waste paper and different cellulose-rich sludges supplemented with other biomasses were used as substrates for cultivation of Pleurotus spp. Kulshreshtha et al. [22] carried out cultivation experiments using substrates made of handmade paper and cardboard industrial sludges, as well as 50/50 wt $\%$ mixtures of each sludge with wheat straw. The authors found that the time required for the maturity of the fruit bodies in substrates made of the pure sludges was approximately 60 days, and for the mixtures was between 26 and 30 days. The BE for substrates made of the pure sludges was between 3 and $5 \%$, and for the mixtures was between 89 and $94 \%$. Girmay et al. [23] studied substrates made of waste paper and sawdust without supplements. They found that the mycelium growth was faster on substrates made of waste paper than on substrates made of sawdust. The time required for the maturity of the fruit bodies was 37 days for the sawdust and 39 days for the waste paper substrates. The BE across all flushes was approximately 34\% for fruit bodies grown on waste paper and approximately $10 \%$ for sawdust. The authors argue that the low BE of fruit bodies grown on sawdust is due to the lack of substrate supplements. Yildiz et al.
[24] studied substrates made of mixtures of waste paper and leaves of tilia, leaves of European aspen, spruce needles, rice stalk, sawdust, and wheat straw. They compared these substrates with others without waste paper and found that substrates that included waste paper led to a comparable or higher BE. The BE across all flushes was between 40 and $121 \%$.

\section{Mushroom Fruit Bodies Quality}

The nutritional analysis of $P$. ostreatus mushroom fruit bodies grown on the studied substrates is shown in Table 3. For fruit bodies grown on the fibre rejects substrates, i.e., FR40 to FR80, the average contents of crude protein (22.3-25.2 wt \% d.b.), crude fat (3.0-3.5 wt\% d.b.), crude fibre (8.1-9.8 wt\% d.b.), carbohydrates (57.4-61.9 wt\% d.b.), gross energy (358.6-367.6 Kcal/100 g d.b.), and major macronutrients $(\mathrm{Ca}, \mathrm{Mg}, \mathrm{K}, \mathrm{Na}$, and $\mathrm{P}$ ) were comparable to those of the fruit bodies grown on the FR00 substrate. These values are also comparable to those of $P$. ostreatus grown on diverse types of substrates [19, 34].

The contents of main toxic heavy metals in fresh P. ostreatus fruit bodies are shown in Table 4. The concentrations
Table 3 Nutritional analysis of $P$. ostreatus fruit bodies grown on different substrates
Table 4 Contents of main toxic heavy metals in fresh $P$. ostreatus fruit bodies grown on different substrates

\begin{tabular}{llrrrrll}
\hline & Unit & FR00 & FR40 & FR60 & FR80 & $\begin{array}{l}\text { USDA } \\
\text { Data [34] }\end{array}$ & $\begin{array}{l}\text { Koutrotsios } \\
\text { et al. [19] }^{\mathrm{b}}\end{array}$ \\
\hline Crude protein & $\mathrm{wt} \%$ & 21.0 & $25.2 \pm 1.6$ & $22.3 \pm 0.3$ & $23.7 \pm 0.9$ & $30.6 \pm 2.9$ & $14.6-31.4$ \\
Crude fat & $\mathrm{wt} \%$ & 1.0 & $3.2 \pm 0.1$ & $3.0 \pm 0.2$ & $3.5 \pm 0.1$ & $3.8 \pm 0.6$ & $1.6-3.5$ \\
Crude fibre & $\mathrm{wt} \%$ & 6.4 & $9.8 \pm 0.5$ & $9.0 \pm 1.0$ & $8.1 \pm 0.9$ & $21.2 \pm 3.4$ & $12.5-24.3$ \\
Carbohydrates & $\mathrm{wt} \%$ & 67.6 & $57.4 \pm 1.8$ & $61.9 \pm 0.4$ & $60.4 \pm 1.3$ & $56.3 \pm$ n.a. & $56.6-75.9$ \\
Gross energy & $\mathrm{Kcal} / 100 \mathrm{~g}$ & 363.4 & $358.6 \pm 1.7$ & $364.4 \pm 2.9$ & $367.6 \pm 1.6$ & $305.0 \pm$ n.a. & $373-392$ \\
Ash & $\mathrm{wt} \%$ & 6.4 & $8.6 \pm 0.2$ & $7.1 \pm 0.1$ & $7.1 \pm 0.4$ & $9.3 \pm 1.0$ & $6.2-9.9$ \\
$\mathrm{Ca}$ & $\mathrm{g} / \mathrm{kg}$ & 0.3 & $0.6 \pm 0.1$ & $0.3 \pm 0.1$ & $0.8 \pm 0.4$ & $0.3 \pm 0.1$ & $\mathrm{~N} . d$. \\
$\mathrm{Mg}$ & $\mathrm{g} / \mathrm{kg}$ & 1.7 & $1.8 \pm 0.1$ & $1.8 \pm 0.1$ & $2.0 \pm 0.1$ & $1.7 \pm 0.4$ & N.d. \\
$\mathrm{K}$ & $\mathrm{g} / \mathrm{kg}$ & 25.9 & $36.2 \pm 1.3$ & $29.3 \pm 0.6$ & $29.6 \pm 0.4$ & $38.8 \pm 5.9$ & N.d. \\
$\mathrm{Na}$ & $\mathrm{g} / \mathrm{kg}$ & 0.2 & $1.4 \pm 0.1$ & $1.2 \pm 0.2$ & $3.1 \pm 0.1$ & $1.7 \pm 0.3$ & N.d. \\
$\mathrm{P}$ & $\mathrm{g} / \mathrm{kg}$ & 10.1 & $10.2 \pm 0.5$ & $10.4 \pm 0.1$ & $10.5 \pm 0.1$ & $11.1 \pm 1.0$ & N.d. \\
$\mathrm{S}$ & $\mathrm{g} / \mathrm{kg}$ & 1.8 & $2.1 \pm 0.1$ & $1.9 \pm 0.1$ & $2.0 \pm 0.1$ & N.d. & N.d. \\
\hline
\end{tabular}

Values are given as mean \pm standard error in dry basis, $\mathrm{n}=3$

${ }^{\text {a }}$ Values for $P$. ostreatus grown on hardwood

${ }^{\mathrm{b}}$ Minimum and maximum values for $P$. ostreatus grown on diverse types of substrates

\begin{tabular}{lrrrrl}
\hline Metal & \multicolumn{1}{l}{ FR00 } & \multicolumn{1}{l}{ FR40 } & \multicolumn{1}{l}{ FR60 } & \multicolumn{1}{l}{ FR80 } & $\begin{array}{l}\text { Up-limit value set in the EC regu- } \\
\text { lation }(2015 / 1006)[35]\end{array}$ \\
\hline Lead $(\mathrm{Pb})$ & $4.7 \pm 0.1$ & $5.3 \pm 3.9$ & $7.7 \pm 4.3$ & $10.1 \pm 5.0$ & $300 \mu \mathrm{g} / \mathrm{kg}$ mushroom (w.b.) \\
Cadmium (Cd) & $68.0 \pm 0.1$ & $28.5 \pm 5.0$ & $20.5 \pm 0.5$ & $19.0 \pm 3.0$ & $200 \mu \mathrm{g} / \mathrm{kg}$ mushroom (w.b.) \\
Mercury (Hg) & $3.1 \pm 0.1$ & $4.9 \pm 0.8$ & $5.0 \pm 0.6$ & $6.2 \pm 0.4$ & $300 \mu \mathrm{g} / \mathrm{kg}$ fish (w.b.) \\
Arsenic (As) & $6.4 \pm 0.1$ & $26.5 \pm 14.0$ & $48.0 \pm 9.5$ & $53.0 \pm 7.0$ & $0.30 \mu \mathrm{g} /$ day per kg of human body \\
\hline
\end{tabular}

Values are given as mean \pm standard error in $\mu \mathrm{g} / \mathrm{kg}$ wet basis (normalised to $90 \%$ moisture content), $\mathrm{n}=3$ 
of lead $(\mathrm{Pb})$, cadmium $(\mathrm{Cd})$, and mercury $(\mathrm{Hg})$ of the fruit bodies grown on substrates containing fibre rejects were well below the up-limit values for food products set in the EC regulation 2015/1006 [35]. The Cd content of the fruit bodies grown on fibre rejects substrates was lower than that of those grown on the FR00 substrate. There is an evident enrichment of arsenic (As) in the fruit bodies grown on substrates containing fibre rejects. Its content is 3 to 8 times higher than that of those grown on the FR00 substrate, and it ranges from 26.5 to $53.0 \mu \mathrm{g} / \mathrm{kg}$ w.b. depending on the substrate. These amounts are comparable to that of rice sold in the Swedish market, e.g., basmati and jasmine, with average As levels of 63 and $69 \mu \mathrm{g} / \mathrm{kg}$, respectively [36].

\section{Fuel Characterisation of the Spent Substrates}

According to Zhang et al. [14] and Banasik et al. [15], in a well-managed mushroom industry, approximately $70 \mathrm{wt} \%$ d.b. of the initial substrate may remain as SMS that needs to be disposed of. This type of waste could be used as a fuel to produce the heat needed for the pasteurization of substrates and mushroom cultivation processes. This could be a way to create a self-sufficient mushroom production industry that requires very low inputs from external energy sources, and thereby, the costs tied to the production process could be significantly reduced. What follows shows that SMS could be utilized to produce most of the energy needed during the mushroom production processes.

The average elemental composition (SEM-EDS) of the ash produced from the SMS calcined at $1000{ }^{\circ} \mathrm{C}$ is shown in Fig. 3. For the substrates that contain fibre rejects, it can be seen that the ash forming elements are mainly represented



Fig. 3 Average elemental composition (SEM-EDS) of ground ash produced by calcination of the spent substrates at $1000{ }^{\circ} \mathrm{C}$ in terms of weight per cent, normalized for the given elements. Bars refer to the mean \pm standard error, $n=4$ by $\mathrm{Ca}, \mathrm{Si}$, and $\mathrm{Al}$, and that their content increases with an increasing amount of fibre rejects in the substrate.

For FR00 and FR40 SMS, all or a substantial part of the $\mathrm{Ca}$ in the ash comes from the calcium carbonate $\left(\mathrm{CaCO}_{3}\right)$ that was used to adjust the $\mathrm{pH}$ of the substrate. For FR60 and FR80 the Ca comes from the fibre rejects and is mainly from different types of additives used during the production of paper. Paper and cardboard industries employ lime-based additives such as ground and precipitated calcium carbonate $\left(\mathrm{CaCO}_{3}\right)$ as pigments and/or fillers in, e.g., fine paper, cardboard packaging, and other sorts of pulp-based paper. The $\mathrm{Al}$ in substrates with fibre rejects is most probably kaolin $\left(\mathrm{Al}_{2} \mathrm{Si}_{2} \mathrm{O}_{5}(\mathrm{OH})_{4}\right)$, which is also used as filler in different types of paper. $\mathrm{Si}$ is probably colloidal silica $\left(\mathrm{Si}(\mathrm{OH})_{4}\right)$, which is used as retention and drainage aid and also to enhance the frictional and printing properties of paper. All these additives are separated from the cellulose fibre during pulping of the waste paper and end up in the rejects.

During combustion, biomass-based fuels are more or less susceptible to develop problems such as the formation of ash melts that may disturb the normal operation of combustion plants. According to the literature [37], for fuels such as the spent substrates produced in this work, the processes that initiate the formation of ash melts involves K-containing compounds that react with $\mathrm{Si}$ (either from biologically occurring or impurities) and/or phosphorus (particularly for FR00) during the devolatilization and/or char burnout phase. This results in K-rich silicates/phosphates with a low melting temperature. Ash forming matter rich in alkaline-earth metals, such as $\mathrm{Ca}$ and $\mathrm{Mg}$, is thereafter dissolved or react with the K-silicate/phosphate melt, leading to the formation of $\mathrm{Ca} / \mathrm{Mg}-\mathrm{K}$-silicates/phosphates with higher melting temperatures. $\mathrm{Al}$ is known to have a similar effect as $\mathrm{Ca}[38$, 39] and may lead to the formation of Al-silicates with high melting temperature.

The results from the SEM-EDS analysis of the ash produced during calcination at $1000{ }^{\circ} \mathrm{C}$, Fig. 3 , show that $\mathrm{Ca}$, $\mathrm{Al}$, and Si make for 95 to $99 \mathrm{wt} \%$ of the ash formed during combustion of SMS with 40,60, and $80 \mathrm{wt} \%$ fibre rejects. If the results from the EDS analysis are normalized to the contents of $\mathrm{Ca}, \mathrm{Al}$, and $\mathrm{Si}$, and the values recalculated as oxides in mole-\%, one can see that all the ashes from substrates containing fibre rejects fall near the $\mathrm{CaO}$ corner when plotted on the ternary phase diagram (mole-\%) for the $\mathrm{CaO}-\mathrm{Al}_{2} \mathrm{O}_{3}-\mathrm{SiO}_{2}$ system [40], Fig. 4. It can be seen that all melting temperatures of phases in this system are well above the maximum combustion temperatures in the most common combustion technologies used in the industry, i.e., fluidized- and fixed-beds, which is in the order of approximately 800 and $1100{ }^{\circ} \mathrm{C}$, respectively. This probably means that the SMS containing fibre rejects are not prone to develop ash-related problems such as bed agglomeration or slagging. 




Fig. 4 Ternary phase diagram $\mathrm{CaO}-\mathrm{Al}_{2} \mathrm{O}_{3}-\mathrm{SiO}_{2}$ showing the three binary phase diagrams $\mathrm{CaO}-\mathrm{SiO}_{2}, \mathrm{CaO}-\mathrm{Al}_{2} \mathrm{O}_{3}$, and $\mathrm{Al}_{2} \mathrm{O}_{3}-\mathrm{SiO}_{2}$ [40]. The average composition of the ashes produced by calcination

The high Ca content of the fibre rejects SMS probably makes them an ideal fuel for co-combustion with biomasses prone to slagging and bed agglomeration such as straw and different kinds of fast-growing biomasses rich in $\mathrm{K}$ and $\mathrm{Si}$, but with a low $\mathrm{Ca}$ content.

The main drawback that may hinder the utilization of SMS is its high moisture content, around $60-50 \mathrm{wt} \%$ w.b., and it may require drying to achieve a number of purposes in energy applications. Novel drying technologies that allow for quick-drying using low temperature (40 to $90{ }^{\circ} \mathrm{C}$ ) waste-heat are available on the market. Previous works carried out by our research group at the Swedish University of Agricultural Sciences have shown that by using cyclone drying, problematic wastes such as chemical sludge from wastewater treatment at pulp and paper mills [38], cellulose fibre rejects [41], biological sludge [42], and de-inking sludge [43], can be quickly dried at $1000{ }^{\circ} \mathrm{C}$ of the spent FR40, FR60, and FR80 substrates are marked with a red asterisk

to acceptable moisture levels that allow for their use in energy applications. This type of dryer is commercially available, detailed information can be found in a European Patent 1136129B1 [44].

\section{Conclusions}

Cellulose fibre rejects from industrial-scale recycling/pulping of waste paper was used to produce substrates for the cultivation of Pleurotus ostreatus mushroom. Three substrates with 40,60 , and $80 \mathrm{wt} \%$ fibre rejects were tested, and conventional substrate formula based on birch (Betula ssp.) sawdust was used for comparison. The suitability of the spent substrate (SMS) for its use as fuel was assessed through ashing procedures. Mycelium growth was faster on substrates based on fibre rejects. The average biological 
efficiency (BE) of the first flush of fruit bodies grown on fibre rejects substrates was slightly lower than the BE of fruit bodies grown on birch sawdust. The fastest mycelium colonization could, somehow, compensate the lower BE. The fruit bodies grown on fibre rejects substrates have good nutritional values and low contents of heavy metals. There is room for improving the substrate formulation by removing ash from the raw fibre rejects or by the addition of supplements and additives. SMS from fibre rejects could be used as fuel for the generation of the heat needed during the pasteurization of substrates and mushroom cultivation processes and does not represent risks of developing ash-related problems during combustion.

Acknowledgements This work was supported by VINNOVA, The Swedish Energy Agency, and the Swedish Research Council (FORMAS) through the research program RE:source (Grant No. P42481). The Umeå Core Facility for Electron Microscopy (UCEM-NMI node) at the Chemical Biological Centre (KBC), Umeå University, is gratefully acknowledged. The authors wish to thank Carina Jonsson, Gunnar Kalén, and Markus Segerström (Swedish University of Agricultural Sciences, Department of Forest Biomaterials and Technology), for their technical assistance, and Anna-Greta Haglund (Swedish University of Agricultural Sciences, Department of Animal Nutrition and Management) for her help in analysing the mushroom nutritional value. Technical help from Hans Thoren and Anders Kyösti from SCA AB, Obbola, Sweden, is gratefully acknowledged.

Funding Open access funding provided by Swedish University of Agricultural Sciences.

Open Access This article is licensed under a Creative Commons Attribution 4.0 International License, which permits use, sharing, adaptation, distribution and reproduction in any medium or format, as long as you give appropriate credit to the original author(s) and the source, provide a link to the Creative Commons licence, and indicate if changes were made. The images or other third party material in this article are included in the article's Creative Commons licence, unless indicated otherwise in a credit line to the material. If material is not included in the article's Creative Commons licence and your intended use is not permitted by statutory regulation or exceeds the permitted use, you will need to obtain permission directly from the copyright holder. To view a copy of this licence, visit http://creativecommons.org/licenses/by/4.0/.

\section{References}

1. International Council on Clean Transportation (ICCT), Availability of cellulosic residues and wastes in the EU. https://theic ct.org/publications/availability-cellulosic-residues-and-wastes-eu (2016). Accessed 10 August 2020

2. Mäkinen, L., Ämmälä, A., Körkkö, M., Niinimäki, J.: The effects of recovering fibre and fine materials on sludge dewatering properties at a deinked pulp mill. Resour. Conserv. Recy. 73, 11-16 (2013)

3. Monte, M.C., Fuente, E., Blanco, A., Negro, C.: Waste management from pulp and paper production in the European Union. Waste Manag. 29, 293-308 (2009)

4. Grimm, D., Wösten, H.A.B.: Mushroom cultivation in the circular economy. Appl. Microbiol. Biotechnol. 102, 7795-7803 (2018)
5. Rahi, D.K., Rahi, S., Pandey, A.K., Rajak, R.C.: Enzymes from mushrooms and their industrial application. In: Rai, M. (ed.) Advances in Fungal Biotechnology, pp. 136-184. I K International Publishing House Pvt, New Delhi (2009)

6. Croan, S.C.: Conversion of conifer wastes into edible and medicinal mushrooms. Forest Prod. J. 54, 68-76 (2004)

7. Stamets, P.: Growing gourmet and medicinal mushrooms, 3rd Edition. In: Ten Speed Press, USA: (2000) ISBN: 0-89815-608-4

8. Enman, J., Rova, U., Berglund, K.: Quantification of the bioactive compound eritadenine in selected strains of shiitake mushroom (Lentinus edodes). J. Agric. Food Chem. 55, 1177-1180 (2007)

9. Hsieh, H.M., Ju, Y.M.: Medicinal components in Termitomyces mushrooms. Appl. Microbiol. Biotechnol. 102, 4987-4994 (2018)

10. Royse, D., Baars, J.J.P., Tan, Q.: Current overview of mushroom production in the world. In: Zied, D., Pardo-Giménez, A. (eds.) Edible and Medecianal Mushrooms: Technology and Applications, pp. 5-13. Wiley, Singapore (2017)

11. Kilpatrick, M., Sharma, H.S., Lyons, G.: Mushroom compost production-a review of industry quality assurance frameworks in Ireland. In: Proceedings of the 6th International Conference on Mushroom Biology and Mushroom Products, Bonn, Germany. GAMU GmbH, Institut für Pilzforschung, Leiningen (2008)

12. Pardo-Giménez, A., Buendía, P., De Juan Valero, M.R., PardoGonzález, J.A., Zied, J.E.,C., De Cogumelos, D.: M.: Cultivation of Pleurotus ostreatus using supplemented spent oyster mushroom substrate. Acta Hortic. 933, 267-272 (2012)

13. Finney, K.N., Ryu, C., Sharifi, V.N., Swithenbank, J.: The reuse of spent mushroom compost and coal tailings for energy recovery: comparison of thermal treatment technologies. Bioresour. Technol. 100, 310-315 (2009)

14. Zhang, R.H., Li, X.J., Fadel, J.G.: Oyster mushroom cultivation with rice and wheat straw. Bioresour. Technol. 82, 277-284 (2002)

15. Banasik, A., Kanellopoulos, A., Bloemhof-Ruwaard, J.M., Claassen, G.D.H.: Accounting for uncertainty in eco-efficient agri-food supply chains: a case study for mushroom production planning. J. Clean. Prod. 216, 249-256 (2019)

16. Zou, Y., Du, F., Zhang, H., Hu, Q.: Evaluation of korshinsk peashrub (Caragana korshinskii Kom.) as a substrate for the cultivation of pleurotus eryngii. Waste Biomass Valori. 10, 2879-2885 (2019)

17. Mandeel, Q.A., Al-Laith, A.A., Mohamed, S.A.: Cultivation of oyster mushrooms (Pleurotus spp.) on various lignocellulosic wastes. World J. Microb. Biot. 21, 601-607 (2005)

18. Sivagurunathan, P., Sivasankari, S.: Influence of chicken manure on biological efficiency of Pleurotus spp. Waste Biomass Valori. 6, 23-28 (2014)

19. Koutrotsios, G., Mountzouris, K.C., Chatzipavlidis, I., Zervakis, G.: Bioconversion of lignocellulosic residues by Agrocybe cylindracea and Pleurotus ostreatus mushroom fungi-assessment of their effect on the final product and spent substrate properties. Food Chem. 161, 127-135 (2014)

20. Baysal, E., Peker, H., Yalinkiliç, M.K., Temiz, A.: Cultivation of oyster mushroom on waste paper with some added supplementary materials. Bioresour. Technol. 89, 95-97 (2003)

21. Tesfay, T., Godifey, T., Mesfin, R., Kalayu, G.: Evaluation of waste paper for cultivation of oyster mushroom (Pleurotus ostreatus) with some added supplementary materials. AMB Express 10, 1-8 (2020)

22. Kulshreshtha, S., Mathur, N., Bhatnagar, P., Kulshreshtha, S.: Cultivation of Pleurotus citrinopileatus on handmade paper and cardboard industrial wastes. Ind. Crop. Prod. 41, 340-346 (2013)

23. Girmay, Z., Gorems, W.: Growth and yield performance of Pleurotus ostreatus (Jacq. Fr.) Kumm (oyster mushroom) on different substrates. AMB Express 6, 87 (2016) 
24. Yildiz, S., Yildiz, Ü.C., Gezer, E.D., Temiz, A.: Some lignocellulosic wastes used as raw material in cultivation of the Pleurotus ostreatus culture mushroom. Process Biochem. 38, 301-306 (2002)

25. Sithole, B.: New method of measuring the $\mathrm{pH}$ of wood chips. In: Sith, R. (ed.) 59th APPITA Annual Conference and Exhibition: Incorporating the 13th ISWFPC, Auckland, pp. 391-396. Appita Inc., Macleod (2005)

26. Xiong, S., Larsson, R., Atterhem, L.: A method and device for growing of mushrooms/Method and device for pasteurization of a substrate useable for growing mushrooms. Swedish patent SE1651575A1 (WO2018/101872A1)

27. Xiong, S., Martín, C., Eilertsen, L., Wei, M., Myronycheva, O., Larsson, S.H., Atterhem, L., Jönsson, L.J.: Energy-efficient substrate pasteurisation for combined production of shiitake mushroom (Lentinula edodes) and bioethanol. Bioresour. Technol. 274, 65-72 (2019)

28. Wei, M., Xiong, S.J., Chen, F., Geladi, P., Eilertsen, L., Myronycheva, O., Lestander, T.A., Thyrel, M.: Energy smart hot-air pasteurisation as effective as energy intense autoclaving for fungal preprocessing of lignocellulose feedstock for bioethanol fuel production. Renew. Energy 155, 237-247 (2020)

29. AOAC: Official Methods of Analysis, 16th edn. Association of Official Analytical Chemists, Arlington (1995)

30. Fernandes, Â., Barros, L., Martins, A., Herbert, P., Ferreira, I.C.F.R.: Nutritional characterization of Pleurotus ostreatus (Jacq. Ex Fr.) P. Kumm. produced using paper scraps as substrate. Food Chem. 169, 396-400 (2015)

31. Jennische, P., Larsson, K.: Traditionella Svenska Analysmetoder för Foder och Växtmaterial (Traditional Methods for Analysis of Feed and Plant Material). SLL rapport nr 60, Uppsala (1990).(in Swedish)

32. Bahlsberg-Pålsson, A.M.: Förbehandling, Uppslutning och Extraktberedning av växt-och Förnaprov. Handledning i Kemiska Metoder vid Växtekologiska Arbeten, pp. 18-19. Meddelande från Växtekologiska avdelningen, Lunds Universitet, Lund (1990).(in Swedish)

33. Baldrian, P.: Fungal laccases - occurrence and properties. FEMS Microbial. Rev. 30, 215-242 (2006)

34. United States Department of: Agriculture (USDA) food composition databases, National Nutrient Database for Standard Reference 28. https://ndb.nal.usda.gov/ndb/search/list (2018). Accessed 10 August 2020
35. European Commission (EC), Regulation 2015/1006. Official Journal of the European Union L 161/14 (2015)

36. Livsmedelsverket: Pat 3 - Risk management - Inorganic Arsenic in Rice and Rice Products on the Swedish Market, report 16. https ://www.livsmedelsverket.se/globalassets/publikationsdatabas/ rapporter/2015/inorganic-arsenic-in-rice-and-rice-products-onthe-swedish-market-2015-part-3-risk-management.pdf (2015). Accessed 10 August 2020

37. Boström, D., Skoglund, N., Grimm, A., Boman, C., Öhman, M., Broström, M., Backman, R.: Ash transformation chemistry during combustion of biomass. Energy Fuel 26, 85-93 (2012)

38. Grimm, A., Etula, J., Salh, R., Kalén, G., Segerström, M., Brücher, J., Söderberg, C., Soukup, D., Pfeifer, C., Larsson, S.H.: Slagging and fouling characteristics during co-combustion of Scots pine bark with low-temperature dried pulp and paper mill chemical sludge. Fuel Process. Technol. 193, 282-294 (2019)

39. Wang, L., Becidan, M., Skreiberg, Ø.: Sintering behavior of agricultural residues ashes and effects of additives. Energy Fuel 26, 5917-5929 (2012)

40. Pöllmann, J.: Chapter 2: composition of cement phases. In: Barnes, P., Bensted, J. (eds.) Structure and Performance of Cements, 2nd edn. CRC Press, Boca Raton (2001)

41. Grimm, A., Elustondo, D., Mäkelä, M., Segerström, M., Kalén, G., Fraikin, F., Léonard, A., Larsson, S.H.: Drying recycled fiber rejects in a bench-scale cyclone: influence of device geometry and operational parameters on drying mechanisms. Fuel Process. Technol. 167, 631-640 (2017)

42. Mäkelä, M., Geladi, P.: Response surface optimization of a novel pilot dryer for processing mixed forest industry biosludge. Int. J. Energy Res. 39, 1636-1648 (2015)

43. Lähdeniemi, A., Mäkelä, M., Dahl, O.: Drying/fractionation of de-inking sludge with a high velocity cyclone. Dry. Technol. 31, 378-384 (2013)

44. European Patent 1136129B1, Two-stage comminuting and dehydrating system and method. Proprietor: Airgrinder, A.B., Skelleftehamn, Sweden. https://encrypted.google.com/patents/EP113 6129B1?cl=no (2019). Accessed 10 August 2020

Publisher's Note Springer Nature remains neutral with regard to jurisdictional claims in published maps and institutional affiliations. 